\title{
Assessing Economic Losses of the Small River Ecosystems and Developing of Compensation Measures within the Framework of Sports Facilities Construction
}

Derevenskaya O.Yu.

Kazan Federal University, Kazan, 420008, Russia

Mingazova N. M.

Kazan Federal University, Kazan, 420008, Russia

Mingaliev R.R.

Kazan Federal University, Kazan, 420008, Russia

Pavlova L.R.

Kazan Federal University, Kazan, 420008, Russia Email address: oderevenskaya@mail.ru

Doi:10.5901/mjss.2014.v5n18p345

\section{Abstract}

The article describes the basic theoretical principles that underpin the economic calculation of environmental damage in the course of human economic activity. As an example the assessing of the losses from the impact of the construction of sports facilities in the floodplain of a small river. We have calculated the environmental losses arising in the course of preparation and construction activities. Developed compensatory measures that reduce the effects of damage caused by the construction work.

Keywords: economic losses, assessment, compensation measures, small river, ecosystem.

\section{Introduction}

Construction of various facilities is a form of impact on the environment and usually leads to negative consequences causes' economic damage. Legislation of the Russian Federation is assumed assessment of environmental harm caused to the environment, natural resources, public health and reparation of damage.

Kazan is the city of the 2013 Universiade. During the preparation for this important international sports events sports facilities construction projects are developed and implemented, including the football stadium. The construction site is located in the floodplain of a small river Kazanka.

Physical and geographical zoning of Kazanka River is the forest zone of Vyatsko Kamskaya upland of the Middle Volga on the East European Plain. Floodplain has a high natural value. This is the basis of natural environmental pillar, the habitat of rare species of plants and animals, a place of recreation for residents of Kazan. Kazanka River declared a natural sanctuary and has economic, cognitive and recreational value [3].

Construction and exploitation any sports facility must meet the requirements of the International Committee of Sports. They must also integrate harmoniously with the landscape and the city's infrastructure, as well as comply with environmental protection standards and requirements. The aim of this work was to assess the environmental damage caused by the implementation of the project and to develop compensation measures.

\section{Method}

Construction work was carried out in 2009-2013. Environmental damage that has occurred to the environment, water area and the flood plain of Kazanka river consists of the following: damage from cutting green plants; damage from fish mortality and loss of food organisms; damage caused by pollution of the river from suspended solids; damage from soil pollution; damage caused to rare species of flora and fauna. Equation to calculate the environmental damage are given 
below.

Damage from felling trees and shrubs were calculated according to the formula:

$\mathrm{P}=\mathrm{B}_{\mathrm{pj}} \mathrm{K}_{1} \mathrm{~K}_{1} \mathrm{~K}_{3}{ }^{*} \mid * \mathrm{~N}$,

$P$ - the price the tree which chopped down, rub.; $B_{p}$ - base cost of tree, taking into account the diameter of the tree and the breed, rub.; $j$ - group of trees by their value; $K_{1}$ - correction factor for vital status of green plantations; $K_{3}$ correction factor for functional use of green plantations; I - estimated cost index changes; $\mathrm{N}$ - number of trees $[6,8]$.

Calculation of fisheries from destruction of food organisms was conducted according to the formula:

$N=B * P / B * 1 / K_{2} * K_{4} / 100 * S(V) * k * t_{0} / t_{1} * n$,

where $\mathrm{N}$ - the detriment of fish; $\mathrm{B}$ - average biomass of food organisms (phytoplankton, zooplankton, zoobenthos), $\mathrm{mg} / \mathrm{m}^{3} ; \mathrm{P} / \mathrm{B}$ - coefficient to convert the biomass of food organisms in the production index; $\mathrm{K}_{2}$ - coefficient for the transfer of food organisms in fish production; $\mathrm{K}_{4}$ - figure the maximum possible use of fish forage,\%; $\mathrm{S}(\mathrm{V})$ - size of the area of generation, heap, siltation (turbidity zone volume), $\mathrm{m}^{2}\left(\mathrm{~m}^{3}\right) ; \mathrm{k}$ - mortality rate of food organisms in the impact areas of dredgers; $t_{0} / t_{1}$ - operation time/open water period; $n$ - factor of grams to tons convert $(1 / 1000000)[1,13]$.

Calculation of the volume of capital compensation investments $(K)$ required for the implementation of measures for conservation and restoration of fish stocks carried out according to the formula:

$K=M * K_{0} * 0,12 * t * k i$,

where $\mathrm{M}$ - natural damage, tons; $\mathrm{K}_{0}$ - unit capital investments, thousand rubles/tons of industrial return; $\mathrm{t}$ - time of negative impact on fish stocks; $k i$ - deflator coefficient $[1,13]$.

The size of compensation for harm caused by the degradation of soil and land, determined according to the formula:

$\mathrm{Y}=\mathrm{H} * \mathrm{~K}_{5} * \mathrm{~S} * \mathrm{~K}_{6} * \mathrm{~K}_{7} * \mathrm{~K}_{8}$

where $\mathrm{Y}$ - the amount of recovery for damages, thousand rubles.; $\mathrm{H}$ - standard land value, thousand rubles/ha; $\mathrm{K}_{5}$ regional coefficient; $\mathrm{S}$ - area of degraded land, ha; $\mathrm{K}_{6}$ - environmental condition coefficient; $\mathrm{K}_{7}$ - factor of land protection; $K_{8}$ - factor considering the extent of soil degradation $[10,12]$.

Economic evaluation damage caused to rare species of plants, calculated by the formula:

$Y_{\text {plant }}=\mathrm{N} \cdot \mathrm{K} \cdot$ Minimum wage,

where $Y_{\text {plant }}$ - Economic evaluation of damage, thousands of rubles., $\mathrm{N}$ - the number of dead plants on the territory

under consideration, pcs., $\mathrm{K}$ - factor depending on rarity category of the plant [4] .

Economic evaluation damage caused to rare species, is calculated as follows:

$\mathrm{Y}_{\mathrm{an}}=\mathrm{N}^{*} \mathrm{~K}^{*}$ Minimum wage,

where $\mathrm{Y}_{\mathrm{an}}$ - Economic evaluation of damage, thousands of rubles., $\mathrm{N}$ - The number of dead animals on the territory under consideration, individuals, depending on rarity category [9].

Calculating normative charges for dumping one ton of suspended solids in hydromechanized works conducted according to the formula:

$\mathrm{H}=2,2175 * \mathrm{C} /(\mathrm{Kg}+\mathrm{a})$

where $\mathrm{K}_{9}$ - background concentration of suspended solids mg/liter, a - maximum allowed excess over the background concentration of suspended solids, mg/liter, C - coefficient of fee indexation for environmental pollution [7].

Mass of soil which was released into the slurry during primary water pollution with suspended solids during storage the soil in the underwater quarry is calculated as follows:

$M=n^{*} g^{*} V$,

where $\mathrm{n}$ - coefficient, $\mathrm{g}$ - the density of dry soil, tons $/ \mathrm{m}^{3} ; \mathrm{V}$ - the amount of stored soil, $\mathrm{m}^{3}$ thousands $[7,5,2]$.

\section{Results}

\subsection{Assess the damage}

During the construction of football stadium and Water Sports Palace was exerted a significant impact which led to the destruction of valuable parts of the floodplain, floodplain forests and waters of the river with their inhabiting plants and animals, including habitats of rare species of fauna and flora listed in the Red Book of the Republic of Tatarstan [3, 11].

In accordance with the Law "On Environmental Protection" [15] the harm caused to environment shall be compensated in accordance with the duly approved rates and methods of calculating the amount of damage to the environment. In their absence should be conducted on the basis of the actual costs of restoration of the state of the environment taking into account the losses incurred, including lost profits.

For calculation of damages following the injury, deaths and destruction of all types of property and resources, 
including natural resources and objects next economic formula is widely used at the present time: losses = restoration of the right + actual damages + loss of profits, actual damages = loss or damage of property, loss of profit $=$ lost revenue.

Economic meaning of the formula is that the amount of damages determined by summing the costs necessary to restore the violated object (to bring it to the original state), the cost of the lost object and damages caused by the nonreceipt of expected income. Procedure for calculating harm caused to some natural objects which is fixed various kinds of legislative and other legal acts based on the same formula. Thus, environmental damage assessment includes two items: a) the actual environmental harm caused to the environment and natural objects - land, soil, water, air, greenery; b) loss of the municipality, a legal entity or any other actor of civil relations due its occurrence and the need to eliminate the consequences at the expense of the city. The minimum amount of losses can be determined by the costs of rehabilitation of area and elimination of pollution of air and water [14].

These fundamental principles have been used in calculating the damage to the environment during the construction of sports facilities in the floodplain of Kazanka River (Kazan, Russia). The size of environmental damage caused under construction was evaluated in a total of 4 million 808 thousand 429 \$(Table 1).

Table 1. The final estimate of the amount of environmental damage

\begin{tabular}{|l|c|}
\hline Type of damage & Amount, \$ \\
\hline Damage to trees and shrubs & 2602953 \\
\hline Fisheries damage & 497747 \\
\hline Damage to soils & 1026844 \\
\hline Damage caused to rare species of plants and animals listed in the Red Book of the Tatarstan Republic & 662658 \\
\hline Damage from water pollution with suspended solids & 18227 \\
\hline Total & 4808429 \\
\hline
\end{tabular}

\subsection{Development of compensation measures.}

Compensation measures for environmental remediation it is any action taken to compensate for temporary losses associated with environmental degradation, which arises from the moment of harm and lasts until the restoration of the environment to its steady state. Carrying out compensation measures when implementing major infrastructure projects it is brand new phenomenon for Russia, not enough regulated at the legislative, executive and controlling authorities.

Compensation measures were developed based on the following environmental principles. Principles are based on the requirements of water quality in the river and functioning environmental framework of the city: preserve the mode in flow; maximum preservation of habitats or create the necessary conditions for new sites; conservation and enhancement of biodiversity of plants and animals.

Preserve the mode in flow means keeping and deepening the duct between the islands and streams that implement natural drainage areas. Flowage provides natural aeration of water and accelerates the process of selfpurification. The principle of maximum habitat conservation and the creation of suitable conditions in new areas means, first of all, the creation of spawning habitat of phytophilic fish species. Populations of these species is suffered the most due to backfill of shallow waters. The principle of maintain and increase the biodiversity of plants and animals means that the transformation of water area and coastal areas should not only reduce, but, on the contrary, increase the biodiversity of the natural system. Restoration of lakes, streams, creeks, coasts will allow for a work on the artificial creation of the lost environmental systems and potentially to the possible introduction of a rare plant species in urban gardening practices.

The following can be implemented as a compensation measures:

1. Recreational improvement of parks in the floodplain of Kazanka River (total area approximately $80 \mathrm{ha}$ ).

2. Clearing the riverbeds and partially channels. Cleaning the river waters and coastline from the household and construction waste, removal of contaminated sediments, their replacement by clean river sand, gravel and pebbles. Fortification of coasts in areas of intense erosion processes through modern bioengineering techniques.

3. Clearing and floodplain lakes and reconstruction of water pass in floodplains through dams.

4. Water aeration in the ducts and river.

5. Floodplain biological recultivation conducting (protection and restoration of spawning, fish stocking of the river, biological reclamation of soils that have been degraded during construction, etc.).

6. Greening the coasts of the Kazanka river on the surrounding areas, the creation of new parks. 
Implementation of a set of measures will partially able to compensate the damage caused to the environment during the construction of sports facilities, maintain water quality in the river at the same level, partly preserve the environmental functions performed by the floodplain in Kazan.

\section{Conclusions}

To conclude, in the course of the research assessment of the environmental damage caused to the environment during the construction of sports facilities in the floodplain of Kazanka river (Kazan, Russia) was performed. Total amount is 4808429 \$. Compensatory measures implementation of which will reduce the damage caused to the environment have been developed.

\section{References}

Calculation methodology damage to fisheries as a result of violations of the Rules of fisheries and protection of fish stocks, approved by the Ministry of Fisheries on 07.12.74 № 30-2-02, the Ministry of Finance and of 07/15/74

Calculation methodology of damages caused to the state in violation of water legislation (RD 33-5.3.01-83).

Ecology of Kazan. - Kazan: «Фen», 2005. - 576 p.

Government Decree of 21.05.2001 № 388 "On approval of rates for calculation of compensation for damage caused to the forest fund and not part of the forest fund, violation of forest legislation of the Russian Federation"

Guidelines for the calculation of fees for unorganized discharge of pollutants into water bodies "(approved SCEP from 23.06.2000 № 0222/24-151).

Guidelines for the evaluation and compensation of damage caused to the environment as a result of environmental offenses, approved by the Russian State Committee on 06.09.1999

Instructions and guidance on charging for environmental pollution Registered in the Ministry of Justice on March 24, $1993 \mathrm{~N} 190$.

Interim Procedure for Assessing Preventable Environmental Damage. 09.03.1999 Russian Federation Goskomekologiya.

Methods of assessing damage and calculating the amount of damage caused by the destruction of wildlife and their habitat violations (SCEP approved April 28, 2000).

Methods of determining the extent of damage from soil and land degradation (approved by the Ministry of Russia from 11.07.1994, the Goskomzem and Russia in 1994, Russia agreed Minselhozprodukt 1994).

Mingazova N.M., Derevenskaya O.Yu., Mukhachyov S.G., Nabeeva E.G., Palagushkina O.V., Unkovskaya E.N., Zaripova N.R. Monitoring the condition of river Kazanka in Kazan and the development of compensatory measures // Ecology urbanized areas, 2013. № 2. - P. 121-126.

Procedure for determining extent of damage from contaminated land chemicals (approved Roskomzemom November 10, 1993 and Ministry of Natural Resources November 18, 1993)

Temporary method of estimating the damage to fish stocks as a result of construction, renovation and expansion of enterprises, buildings and other objects and different types of work in fisheries waters ", approved by Ministry of Fisheries, Russian Federation Goskomekologiya, the Ministry of Finance of the USSR (Moscow, 1989).

Temporary typical method of determining the cost-effectiveness of environmental activities and assess the economic damage to the national economy of pollution (approved by Resolution of the USSR Gosplan USSR State Construction Committee, the Presidium of the USSR Academy of 21.10.1983 N 254/284/134)

The Federal Law "On Environmental Protection" of 10.01.2002 № 7-FZ. 